\title{
The Second Wave of Incorporation in Latin America: A Conceptualization of the Quest for Inclusion Applied to Argentina
}

Federico M. Rossi

\section{ABSTRACT}

Between 1996 and 2009, a process of struggle for and (after 2002) partial achievement of the second incorporation of the popular sectors took place in Argentina. This process involved a combination of routine and contentious political dynamics that reformulated state-society relations in the postcorporatist period. As a continuation of the first incorporation (1943-55), the second incorporation displayed some similar features; other attributes were specific to this second process, mainly that it was not corporatist but territorial and that the central agents of transformation were not trade unions but the disincorporated popular sectors, which were territorially organized into a "reincorporation movement." This article conceptualizes these dynamics and analyzes the role played by the main political actor related to this historical process, the piquetero (picketer) movement.

We want to return to factories. We said to the [national Labor] Ministry that we are socialists; that we question the private ownership of the means of production; that we struggle for a workers' state-but that we won't wait for the revolution to return to the job market. We want to be exploited by a capitalist again.

-Néstor Pitrola, national piquetero leader of the Trotskyist Polo Obrero social movement organization (La Nación 2004).

\begin{abstract}
What did it take to bring a key national Trotskyist leader to demand that the government allow workers to be exploited by capitalists again? Although it may seem contradictory at first glance, this leader's request was the logical result of the effects of neoliberal reforms on Latin American politics and society. Neoliberalism has been defined as crucial to the reformulation of state-society relations in the postcorporatist period because it has undermined the national-populist or statecentered matrix (Cavarozzi and Garretón 1989) through the weakening, and sometimes destruction, of existing corporatist arrangements (Oxhorn 1998; Collier and Handlin 2009b).
\end{abstract}

Federico M. Rossi is a research fellow at the Center for Inter-American Policy and Research, Tulane University. federicorossi@yahoo.com.ar 
Neoliberalism has also caused the sociopolitical exclusion or disincorporation of the popular sectors (see Tokman and O'Donnell 1998; Portes and Hoffmann 2003). ${ }^{1}$ However, exclusion was intensely resisted by social movements mobilizing the popular sectors, such as the landless peasants in Brazil, the indigenous in Bolivia and Ecuador, and the unemployed in Argentina (Almeida 2007; Ondetti 2008; Silva 2009; Becker 2011), contributing to a resurgence of the left.

A growing body of literature is examining the turn toward leftist governments (Panizza 2009; Cameron and Hershberg 2010; Weyland et al. 2010; Levitsky and Roberts 2011a). Some scholars associate what might be considered as the end of neoliberalism with the accession of left-wing or populist parties to power in Argentina, Bolivia, Brazil, Ecuador, Uruguay, and Venezuela (Grugel and Riggirozzi 2009,2012 ). While the access to power of some left-wing or populist parties seems to be relevant for the application of inclusionary policies (Huber and Stephens 2012), this article will argue that we need to add extra layers of empirical detail and theoretical density to the "left turn" thesis to explain the complexity of the macroprocess of transformation in Latin America's political arena.

This article proposes an explanation for the major process of transformations behind the "left turn": the second wave of incorporation of the popular sectors, illustrated with the case of Argentina. The "second wave of incorporation" means the second major redefinition of the sociopolitical arena in Argentina, caused by the broad and selective inclusion of the popular sectors in the polity after being excluded or disincorporated by military authoritarian regimes and democratic neoliberal reforms. The article argues that the second wave of incorporation is the result of the accumulation of transformations that were carried out to deal with the contentious struggle for reincorporation by the popular sectors, organized in territorialized social movements. The emergence of left-wing or populist parties in government is one of the byproducts of two decades of struggles against disincorporation. ${ }^{2}$

This article conceptualizes the dynamics of the popular sectors' struggle for their reincorporation into the sociopolitical arena and analyzes the role played by the main political actor related to this historical process, the piquetero movement. Given that the piqueteros emerged as a byproduct of the transformations caused by neoliberalism, their movement represents a paradigmatic case of a specific type of movement conceptualized in this article: a "reincorporation movement."

This analysis applies a qualitative process-tracing method based on the triangulation of interviews with key actors, newspaper data, and archival material to study the process (second wave of incorporation) and actor (reincorporation movement) that have partially reshaped the sociopolitical arena in Argentina and perhaps also elsewhere in the region. ${ }^{4}$ This article continues the work done in some studies of the neoliberal period (Cavarozzi and Garretón 1989; Oxhorn 1998; Roberts 2002, 2008; Silva 2009) by outlining what happened after the period of resistance to recommodification ended. It also complements the analyses of postneoliberalism that have focused on unions (Etchemendy and Collier 2007), parties (Levitsky and Roberts 2011a; Flores-Macías 2012), and community organizations and NGOs (Collier and Handlin 2009a), along with the role played by social movements. ${ }^{5}$ 
The article first defines "reincorporation movements and struggles" and illustrates this conceptualization with the paradigmatic case of the piqueteros. It continues with the definition and analysis of the main characteristics of the second wave of incorporation in Argentina. The second half of the article historically analyzes the second wave of incorporation and the central role played by the piqueteros in this process. The article concludes with a brief cross-national comparison of Argentina and other Latin American cases that also could be considered examples of the second wave of incorporation.

\section{CONCEPTUALIZATION OF (RE)INCORPORATION STRUgGLES AND MOVEMENTS}

Neoliberal reforms have produced a change in the focus of protest in Latin America: now it mainly occurs in the quest for recognition by the state (Delamata 2002; Auyero 2003). This quest for recognition is part of what I call the struggle for (re)incorporation. ${ }^{6}$ I use this term because although most actors in this quest present discourses of radical societal transformation, those discourses have actually unfolded as types of collective action that can be deemed "bridging with the state" (apart from the unintended transformations produced by the incorporation of the actors). By "bridging with the state," I mean types of collective action that aim to (re)connect excluded segments of society with state institutions to recover-or for the first time gain - access to rights and benefits that the state has failed or ceased to secure or provide. The piqueteros' claim to unemployment subsidies, housing, and other benefits is an example of this "bridging" collective action because it reconnects the popular sectors with the state as a provider of some benefits and rights.

Much of the initial research conducted on the piqueteros came about because of the interest in this "quest for recognition" from governments that had previously ignored the poor and unemployed. However, this literature has overlooked a crucial question: if the state is the main institution structuring social relations in a society, what exactly should movements challenge when the state reduces its structuring role? It seems that it is the absence of - or lack of due regard for-the structuring of certain types of social relations that movements must challenge. Protest is thus a substantial and moral tool for popular sectors to form a bridge between the state as it actually is and the state as it should be. In other words, what the piqueteros struggle for, like the landless peasants in Brazil, is the presence of the state as more than a merely repressive institution. In this sense, reincorporation struggles are historically linked to the heritage of the incorporation of the first laborers into the political arena. The consequences of the neoliberal reforms explain the demand for a return of the state presence as an articulator of social relationships.

Therefore, what differentiates recognition struggles from those for (re)incorporation? I argue that the two are intimately related. The pursuit of recognition might be defined as the initial quest linked to the popular sectors' disruptive emergence in protest. After some degree of recognition has been achieved (i.e., unemployment subsidies, media attention, etc.), the claim organized as a movement will usually lead 
to socioeconomic conflicts and the quest for incorporation. In societal terms, a popular sector's struggle for recognition might lead to a struggle for incorporation—or reincorporation - as a subject and member of society that merits esteem and is entitled to some of the rights that the (neoliberal) context has (abruptly) altered. In this sense, it is both a moral economy issue and a specific process attached to the constitution of the polity through its expansion or contraction.

Another reason for defining recognition and reincorporation as intimately linked struggles is that no quest for reincorporation can emerge without a prior claim for recognition; it is that first claim that constitutes a new "social question." However, the quest for recognition does not necessarily evolve into one for reincorporation, as it can be a goal in itself (e.g., claims for a multilingual society). In other words, when discussing popular sector movements, struggles for recognition should be considered as the first stage of the legitimation of both the claim and the actor. If organized into a movement, this process will evolve toward the dynamics of incorporation. The piquetero movement can be defined as a type of actor that is particular to the consequences of neoliberalism, and one that is related to equivalent processes of disincorporation and reincorporation in Latin America since the 1980s.

\section{Definition of Reincorporation Movements}

Reincorporation movements share many of the longstanding characteristics of the popular sector movements' quest for social transformation through inclusion, by revolution or reform. At the same time, they have specific attributes that mark them as particular expressions of the historical process of struggle for incorporation that emerged with neoliberalism (at least in Latin America). As such, reincorporation movements use the repertoire of strategies and legacies accumulated in the initial incorporation period while pushing for the reestablishment of the tie between the popular sectors and the sociopolitical arena in the quest for reintegration into the polity. In Argentina, this tie reconstruction was executed through the intertwining of preexisting practices in a new scenario with somewhat different actors: a social movement (albeit heavily influenced by trade unionist practices) and a state prepared to deal only with already established neocorporatist actors. This new context for the inherited repertoire led to the recycling of strategies with new claims; for example, trade union-style negotiations for food distribution. A pattern of interaction between government and movement was thus established through new institutions or the redefinition of roles of existing institutions.

Therefore, "reincorporation movements" can be defined as a gestalt composed of six categories. ${ }^{7}$ Two of these are central and universal, with four subcategories that logically depend on the first two and must be adapted to each cluster of cases studied to explain more specific national or regional patterns. The two central categories in this definition of reincorporation movements are the following:

1. Period of emergence. These movements are byproducts of the disincorporation process that started in the 1970 s and a result of the crisis of party communities and mass-based labor parties set up in the 1980s and 1990s. ${ }^{8}$ 
2. Demands. Claims for inclusion predominate, even though these could be framed by the leaders as "revolutionary" in their long-term goals."

Reincorporation movements are also defined by the following noncentral categories, which can be seen to have these common attributes:

3. Method and locus of protest. Radical methods of protest, such as insurrectional direct actions, tend to be used, while the movements are contemporaneously open to negotiation with government. Their locus of protest is generally the territory.

4. Leadership. Leaders come mainly from trade unions, Christian base communities, and former guerrilla organizations.

5. Organizational format. These movements are loose, territorialized networks of highly vertical organizations.

6. Perception of democracy. These movements make a positive re-evaluation of the value of democracy as a political regime, insofar as it is perceived as necessary and reforms are, in some cases, achieved by electoral means.

To summarize, the basic assumption underlying the historicist definition proposed here is that the second wave of incorporation is attached to the emergence of a specific type of political actor. Therefore, many movements are not of the reincorporation type because, even though they may share some of the noncentral categories, they are not explained by at least one of the central categories. Examples of this are cultural or countercultural movements, environmental movements, anti-immigration or xenophobic movements, and separatist or pro-independence movements. The benefits of defining a type of movement as associated with a particular historical period in a region is that this (historical and geographical) context allows for conceptualizations that encompass the distinctiveness of these types of movements.

\section{The Piqueteros And (RE)InCorporation STRUGGLES IN ARGENTINA}

Since 1996, the piquetero movement has mobilized the poor and unemployed people of Argentina, providing organizational structure to their quest to end neoliberalism and see themselves reincorporated into a more inclusive and equal society. During this time, the movement has become increasingly organized, developing into a network of confrontation-oriented actors that is still active more than a decade later. As with any movement, the piqueteros are formed of several social movement organizations. While the number of main organizations making up the movement has gradually expanded, it originated from three key groups: the Guevarist and autonomist Movimientos de Trabajadores Desocupados (MTDs), the Maoist Corriente Clasista y Combativa (CCC), and the Liberation Theologyinspired Federación de Trabajadores por la Tierra, Vivienda y Hábitat (FTV).

The struggle of the piquetero movement from the 1990s to the 2000s cannot be explained through co-optation- or clientelism-based accounts of piquetero-govern- 
Table 1. Historical Sequence of Stages in the Popular Sectors' Struggle for Incorporation in Argentina, 1915-2009

\begin{tabular}{ll}
\hline \hline $1915-1943$ & Reform \\
$1943-1955$ & Party corporatist incorporation \\
$1955-1962$ & Aftermath-Heritage-Coup \\
$1962-1976$ & Equilibrium/Zero-sum game \\
$1976-1996$ & Coup-Disincorporation \\
$1996-2002$ & Recognition-Legitimation \\
$2002-2009$ & Party territorial reincorporation \\
\hline \hline
\end{tabular}

Source: Stages for the period 1915-62 from Collier and Collier 1991.

ment interaction; the process is more complex than these may suggest (Pereyra et al. 2008; Pérez and Natalucci 2012; Rossi forthcoming). The piqueteros' struggle is part of a long-term quest by the poor people of Argentina for sociopolitical participation in the polity. If we take this long-term perspective, the historical sequence of stages in the popular sectors' struggle for incorporation in Argentina can be synthesized as shown in table 1. For the first incorporation, Collier and Collier (1991, 22, figure 0.1 ) assert that the process in Argentina followed the logic of reform-incorporationaftermath-heritage-coup. ${ }^{10}$ After the coup stage, a process of disincorporation started, which ended when the process shifted into one for reincorporation after the state recognized the claim for sociopolitical inclusion and the piquetero movement was legitimated as a new political actor.

\section{First and Second Incorporations}

The first incorporation has been defined as "the first sustained and at least partially successful attempt by the state to legitimate and shape an institutionalized labor movement" (Collier and Collier 1991, 783). In Argentina, the first incorporation was a corporatist process that took place between 1943 and 1955. ${ }^{11}$ It involved a combination of the mobilization of popular claims by trade unions at the factory level and the Peronist Party policies for channeling those claims into corporatist institutions.

The second incorporation happened between 2002 and 2009. As a process, the second wave departed from the inherited institutions and actors of the first incorporation. In addition, the two waves of incorporation were partial and selective, redefining the relationship between the popular sectors and the state. Like the first, the second incorporation was a predominantly urban and industrial process, and rural peasants were not included, due to their marginal relevance to national politics. However, in this second wave, the main actor mobilizing the claims of the poor and excluded was the piquetero movement, organizing the disincorporated popular sectors at the territorial level. Again, a Peronist party was in charge of developing the policies for channeling these new claims. However, in this case, they were not the old corporatist institutions but new or reformulated institutions conceived in response to the territorialized nature of the claims that emerged with this movement. 
This second wave was "territorial" because the incorporation of the popular sectors was predominantly done through institutions created or reformulated for the articulation of actors that were not functionally differentiated. This was a result of the emergence of contentious claims for reincorporation outside the trade union system. Instead, neighborhoods and shantytowns became central spaces for claim making for the organized poor people (Cerrutti and Grimson 2004; Merklen 2005) once neoliberal reforms and authoritarian regimes had weakened or dissolved neocorporatist arrangements for resolving sociopolitical conflicts. For this reason, the social policies to reincorporate the popular sectors were not function- or class-based but territory-based (i.e., defined by the physical location of the actors). ${ }^{12}$

This was an important shift from the functionalist logic of corporatism, which had articulated the popular sectors' claims through trade unions as their sole representative actor and through the Ministry of Labor as their exclusive state department. To sum up, because they were not seen as serving a clear "function" for institutions with a corporatist logic, the disincorporated popular sectors were targeted by policies based on where they were located and the multiplicity of needs associated with their situation, and not only as workers without jobs.

As part of the recursive dynamics of incorporation, both waves shared some elements in the sequencing of incorporation. Both incorporation periods were preceded by a (neo)liberal phase that created a new "social question." This "social question" in both cases evolved into a political question with a contentious actor that was gradually recognized and legitimated. In the period 1990s to 2000s, the emergence of unemployment as a new "social question," the modification of policing techniques, and the creation of massive social programs can be seen as a process equivalent to that of the preincorporation dynamics. Between the 1870s and the 1930s, anarchists, syndicalists, and socialists posing the "social question" pushed the elites to create anti-immigration and security laws (Isuani 1985; Suriano 1988) to recognize the claim to social rights and later the actor behind this new claim, the labor movement (Suriano 2000). Concerning social policies, in the first wave this process led, ultimately, to the creation of the Secretariat of Employment and Social Security in 1943 (Gaudio and Pilone 1983, 1984). In the second wave, it led to the creation of the Ministry of Social Development in 1999.

While these parallels allow us to talk about two waves of incorporation, they do not mean that history has repeated itself. There are elements of iteration and innovation in a process that is, as such, like a collage. It is also important to bear in mind that incorporation waves should not be equated with the constitution of a more equal society or the creation of a welfare state but with the reshaping of the political arena by redefining and expanding the number of legitimate political actors. ${ }^{13}$

In a nutshell, the argument in the following pages is the following. After the first incorporation, the coup of 1976 ushered in a period of neoliberal disincorporation. In consequence, a new "social question" was created, associated with the victims of austerity or authoritarianism. This "social question" morphed into a political issue as a result of the popular sectors' contentious quest for, first, recognition of their suffering, and then their claim for reincorporation into the sociopolitical arena as citizens 
and wage earners. In 1996, the mobilization of the poor and disincorporated was organized into the piquetero movement. Since 2001, this movement has gradually come to be legitimated as a new national political actor, expanding the political arena. Simultaneously, as before and during the first incorporation, the new "social question" evolved into specific institutions, social policies, and policing innovations that gradually and selectively reincorporated the popular sectors into the sociopolitical arena. The process-tracing analysis of these dynamics is what follows.

\section{NeOliberal Disincorporation, 1976-1996}

The neoliberal reforms that started the process of the recommodification of relations in the 1970s can be interpreted as a process of disincorporation, thereby redefining the main populist versus conservative political cleavage (Roberts 2002, 2008), as well as the roles of political actors involved in the first incorporation process of the 1950s. However, neoliberal disincorporation does not entail a total rupture with the past, as there are certainly elements of continuity.

In concrete terms, after the end of corporatist inclusion (1943-55), consolidated during the import substitution industrialization (ISI) model, Argentina went through a period of stalemate between the Peronist movement and the other political actors (O'Donnell 1973). This situation collapsed after the bureaucratic-authoritarian state model was imposed during the military regime of 1966-73 (O'Donnell 1998; Collier and Collier 1991), only to re-emerge after a short democratic spring (1973-76). Indeed, a new and more resolutely oppressive military coup in 1976 definitively initiated a disincorporation process by systematically applying repressive policies so as to demobilize the popular sectors and leftist groups-with the extrajudicial killing of thousands of activists - while concurrently dismantling the ISI model in favor of a more neoclassical, liberalized economy (Epstein 1987; Schvarzer 1998; Novaro and Palermo 2003).

Democratization in 1983 brought with it both pluralism and an expectation of the recovery of welfare through the relaunching of ISI. During Raúl Alfonsín's mandate (1983-89, Unión Cívica Radical, UCR), the Professional Associations Law was reformed, and this allowed the corporate structure of the Peronist Confederación General del Trabajo (CGT) to be maintained and the labor confederation to reassert itself against other corporate structures, such as the Unión Industrial Argentina, the Catholic Church, and the military. By the end of the Alfonsín presidency, the CGT had essentially maintained its monopoly of one union per industry, won back its rights to collective bargaining by sector, and regained control of its social welfare network. However, with the failure of the Austral economic plan, ISI was rapidly dismissed. At the same time, the Latin American debt crisis contributed to a 7.2 percent contraction of Argentina's economy between 1983 and 1985. The hyperinflation crisis of 1989-91 exacerbated the gravity of the situation (Smith et al. 1994; Saad-Filho et al. 2007, 10).

Beginning in 1991, a heterodox, neoliberal reform program was implemented during the presidency of Carlos Menem (Peronist Partido Justicialista, PJ) with 
the urgent intention of resolving the hyperinflation crisis (Palermo and Novaro 1996). These reforms were applied in two stages. The first stage was to introduce stabilization policies to solve the debt and fiscal crises and hyperinflation. The focus was on the privatization of state-owned companies and the liberalization of ISI regulations, with a neoclassical economic perspective (Haggard and Kaufman 1995; Oszlak 2003). The second stage focused on the restructuring of the public sector through decentralizing and reformulating social policies, moving from a universalist to an individualistic approach (Tokman and O'Donnell 1998; Oxhorn 1998; Orlansky 1998). Foremost among the mixed results of the neoliberal reforms in Argentina was a rapid phase of deindustrialization. Although in 1989, 31 percent of GDP was based on manufactured products, by 2001 the rate was just 17 percent (Saad-Filho et al. 2007, 24). This led to an increase in the number of precarious and informal types of labor arrangements and a more uneven distribution of income (Altimir and Beccaria 2001; Portes and Hoffmann 2003); this was related to a concomitant increase in unemployment from a historical average of 5 percent to 18.4 percent in 1995 -with a peak of 21.5 percent in 2002 (INDEC 1974-2003).

In Argentina, the labor movement has traditionally been strong and well organized by the Peronist movement. The collapse of ISI and its replacement by a neoliberal model strongly affected the link between the main Peronist organizations and the popular sectors. ${ }^{14}$ The same was true for equivalent labor-based movements elsewhere in the region. ${ }^{15}$

Neoliberalism was also related to the metamorphosis of the dominant Peronist PJ labor-based party into a clientelistic and patronage machine (McGuire 1997; Levitsky 2003). Simultaneously, the state mechanisms for the resolution of societal conflicts were redefined, from a corporatist regime with a hegemonic Peronist CGT to a pluralized, segmented corporatist system (Etchemendy and Collier 2007). Another change in the political arena was the emergence of the piquetero movement as a national political actor, mobilizing a growing constituency of disincorporated popular sectors as they struggled to recover their place in wage-earning society.

\section{The Struggle for REINCORPORATION, 1996-2009}

In 1996, during the period of struggle for reincorporation, a territorialized pattern of interaction between the popular sectors and the Argentine state began to be organized with the emergence of the piquetero movement, and this continued with the second incorporation of the popular sectors that took place from $2002 \mathrm{on}$. The dynamics of this period emerged in the form of a process of reform, resistance, and struggle for reincorporation, all of which contributed to ending neoliberalism.

Reincorporation in Argentina was a contentious process. It was associated with two waves of protest: from the fourth quarter of 1993 until the third quarter of 1996 and from the fourth quarter of 1997 to the fourth quarter of 1999 (Schuster et al. 2006; Herrera 2008). These waves were preceded by a period of great instability 
related to the reorganization of the union system and by a succession of provincial puebladas (social uprisings) that marked the beginning of a contentious resistance to neoliberal reforms. Beginning with the pueblada of December 1993 in Santiago del Estero and the ones between 1993 and 1997 in Jujuy, these actions took place in many provincial capitals, forcing several governors to resign. The number of puebladas grew as resistance by state employees to provincial fiscal austerity policies intensified. Some of the most significant puebladas were those in 1995 in Córdoba (June), San Juan (July), and Río Negro (September and October), and in December 1999 in Corrientes. Owing to the collapse of the regional economies around the Repsol-YPF petroleum enclaves, puebladas also emerged in 1996 (June) and 1997 (March) in Cutral-Có and Plaza Huincul (Neuquén) and from 1997 to 2000 in Tartagal and Mosconi (Salta) (Farinetti 1999; Auyero 2003).

In addition to these waves of protest, the second incorporation process followed a series of stages: recognition of a new "social question," legitimation of the political actor behind the new "social question," and reincorporation of the constituency represented and mobilized by the movement.

\section{From Origin to Recognition, 1996-1999}

In 1996-97, due to the divisions among the local parties and the effects of the cancellation of a "siting decision," unemployed workers began to stage protests in the small cities of Cutral-Có and Plaza Huincul in Neuquén, which depended on oilfield production (Sánchez 1997; Auyero 2003) ${ }^{16}$ The disincorporated popular sectors and public employees protested locally, but despite the widespread increase in these protests, such action during this period actually materialized only in the form of a movement in some districts of Greater Buenos Aires (GBA). This was because only certain areas were endowed with a political context that was favorable to the organization of a movement of disincorporated popular sectors.

Due to the federal, centralized regime in Argentina (Gibson and Faletti 2004, 229), national institutions are close to the most urbanized and industrialized —and abruptly deindustrialized - setting, making GBA a unique location for the spread and consolidation of such movements. Buenos Aires represented one of the most significant pluralist contexts because of the large number of PJ factions and the space for protected contention offered by a few Catholic dioceses, such as Quilmes. Some organizations also had the support of the human rights movement or profited from the territorial strategy of some unions of the recently created Central de Trabajadores Argentinos (CTA). The combination of these available allies, the pluralism of the context, and the high degree of elite factionalization offered a dynamic environment of opportunities for political organization. However, contextual elements are not the only relevant explanatory factors. The emergence of the piquetero movement in specific districts of GBA was also due to an incomparably dense network of activists, which had replaced the armed struggle and party politics with the territorial mobilization of the unemployed urban poor, using a trade unionist rationale (Svampa and Pereyra 2004; Rossi 2013). 
Table 2. Evolution of the Piqueteros' Policy Domain, 1998-2009

\begin{tabular}{ll}
\hline \hline Period & Main Changes \\
\hline April 1998-December 1999 & $\begin{array}{l}\text { Diffusion of the piquetero movement from Neuquén, } \\
\text { Salta, and Jujuy to Buenos Aires, causing the definition } \\
\text { of the "unemployment question" as a national policy } \\
\text { domain with no clear state and society interlocutors. }\end{array}$ \\
December 1999-December 2001 & $\begin{array}{l}\text { Struggle for the definition of the political or social } \\
\text { character of the policy domain and the state depart- } \\
\text { ment responsible for the policy domain between the } \\
\text { Ministries of Labor and Social Development. } \\
\text { Enlargement of the number of legitimate actors dealing } \\
\text { with unemployment policies when Adolfo Rodríguez } \\
\text { Saá becomes the first president to meet with the } \\
\text { piqueteros to define social policies. } \\
\text { Expansion of the restricted policy domain to a general } \\
\text { policy constituency when unemployment policies reach } \\
\text { almost two million persons and when the distribution } \\
\text { of subsidies is no longer under the exclusive control of } \\
\text { mayors and governors. } \\
\text { Participation in/exclusion from the decisionmaking } \\
\text { process for the general social policy with the incorpora- } \\
\text { tion of the FTV, Barrios de Pie, Movimiento "Evita," } \\
\text { and other smaller piquetero organizations in the } \\
\text { Ministries of Social Development and Federal } \\
\text { Planning, but not in the Ministry of Labor. }\end{array}$ \\
May 2003-December 2009 & \\
\hline &
\end{tabular}

Recognition of the unemployment "social question" posed by the piqueteros was a result of the diffusion of social unrest from Neuquén, Salta, and Jujuy to Buenos Aires, along with some internal disputes in Menem's government. The emergence of the piquetero movement marked a new claim and a new type of actor in Argentina's history. This dual novelty made very apparent the total lack of public policies regarding unemployment and, in particular, the lack of state agencies with responsibility for the issue. This had also been evident in the first labor and social rights conflicts related to the so-called social question in the late nineteenth century (Suriano 2000).

The social consequences of neoliberalism were first considered when the Secretariat of Social Development was given to Ramón Ortega in 1998. Since redemocratization, Social Action and Development had been a subsidiary secretariat of the Ministry of Health and Social Action. When Ortega became secretary, Menem moved the department out of the Ministry of Health and made it part of the presidential agencies. Later, in an attempt to become the PJ presidential candidate, Ortega fought with Antonio González (Ministry of Labor) for the responsibility of 
dealing with the unemployment issue, the administration of subsidies, and the upgrading of the secretariat into a ministry (Clarin 1998). González strongly resisted this move and managed to preserve the administration of the Planes Trabajar I and II, and even to create a version III under his ministerial responsibility (Páginal12 1998).

Ortega would lose his battle with González, and the Secretariat of Social Development would remain as such and would gain no control over any policy on employment issues until the end of the Menem presidency. However, Ortega's short presence in the Menem government was the starting point for permanent disputes about the responsibility of the new "unemployment question" between Labor and Social Development in all the subsequent governments. Simultaneously, since the OrtegaGonzález dispute, the "unemployment question" became the "piquetero question." Even though the piquetero movement was not yet considered a legitimate actor on the national level, its claim was still recognized. These ministerial disputes continued until each agency's responsibilities with respect to the piqueteros' policy domain were eventually defined several years later (this process is synthesized in table 2). ${ }^{17}$

\section{From Recognition to Legitimation, 1999-2001}

Following the culmination of the Menem mandate and with the defeat of Eduardo Duhalde (PJ) as presidential candidate, the decadelong territorial agreement that had led, among other things, to the creation of the Historical Rebuilding Fund for GBA between the governments of the nation and the province of Buenos Aires came to an end. ${ }^{18}$ This shift led to the onset of a multiscalar routine and contentious political dispute that is crucial to understand in order to contextualize appropriately the struggle of the piqueteros for legitimation.

These disputes took place, by and large, between the incoming UCR-Frente País Solidario (Frepaso) Alianza national government of Fernando De la Rúa, the Buenos Aires governorship of Federico Ruckauf (PJ pro-Duhalde faction), and the most important municipalities under the control of PJ non-Duhalde factions (e.g., La Matanza). Due to Argentina's centralized federal regime, the territorialized nature of the legitimation struggle preserved its locus in GBA during this period. In addition, the new, coalitional structure of the executive branch gave rise to several disputes between the Frepaso and the UCR concerning the control of the main state areas linked to the piqueteros' policy domain. The main conflict was between the Ministry of Labor (UCR allied) and the new Ministry of Social Development (Frepaso). These disputes were crucial to the piquetero movement's ability to cope with the divisions between the two parties in the coalition.

The movement as a whole was legitimated in December 2001, after a deep economic and political crisis led to De la Rúa's resignation. During the weeklong interim presidency of Adolfo Rodríguez Saá (PJ), some of the main piquetero leaders met with the president for the first time. However, the Buenos Aires-based FTV and CCC and the Unión de Trabajadores Desocupados (UTD) of Mosconi (in Salta) achieved legitimation before the rest of the movement, during De la Rúa's 
mandate. Their early legitimation was a result of their increased disruptive power, which had worked to make the "piquetero question" a political issue with a political interlocutor. The Matanzazo coordinated picket by the FTV and CCC, with the support of the mayor of La Matanza and the vice governor of Buenos Aires in 2000, and the puebladas organized by the UTD in Tartagal and Mosconi during the same period, were the main contentious events before the lootings and saucepan-banging protests of December 2001.

While these disruptive events unfolded, the piqueteros' power to mobilize grew, their capacity for coordination expanded, and new organizations were created, such as the Polo Obrero (PO) and the Coordinadora de Trabajadores Desocupados (CTD) "Aníbal Verón" (an alliance of MTDs). However, also during this period, the two major organizations, the FTV and the CCC, underwent significant schisms, leading to an increased number of organizations and disputes in the movement. From the FTV, Barrios de Pie and the Movimiento Territorial Liberación emerged as independent organizations, and the Movimiento Independiente de Jubilados y Desocupados (MIJD) separated from the CCC.

The emergence of the "piquetero question" is related to state innovations in both social policies and the policing of protest. Concerning social policies, the Ministry of Social Development was created in 1999, as were a set of social policies concerning the unemployed, such policies having previously been either underdeveloped or nonexistent (World Bank 2000). These new social policies legitimated the piqueteros as a political actor, delivering state resources to the cooperatives created by the movement (Giraudy 2007). In addition, the allocation of unemployment subsidies was related to protest in combination with the social and economic needs of the provinces (Weitz-Shapiro 2006), but this was done "in order to alleviate the costs of the dramatic rise in unemployment, and to contain the growing social mobilizations" (Lodola 2005, 516).

With regard to policing, important modifications were introduced into the Procedural Penal Code in 2001. Law 24,434 revised articles 184 and 186 and added article 230 bis, increasing the responsibilities of the federal police, the Naval Prefecture, and the Gendarmerie. In practice, this law expanded the responsibilities of the Gendarmerie to include social conflicts. These changes were applied to a social protest for the first time on June 20, 2001 in Mosconi by the Federal Judge of Salta, Abel Cornejo (Página/12 2001). The extended role played by judges in the resolution of sociopolitical conflicts strengthened the judicialization of contentious politics (Artese 2009). ${ }^{19}$ 


\section{From Legitimation to Reincorporation, 2001-2009}

This longer period can be divided into the initial attempt made by the elites for state incorporation (and its subsequent failure) and the continuation and expansion of the incorporation process, this time taking the form of party incorporation. ${ }^{20}$ The reincorporation process started with very high levels of contention between 1996 and 2003, although these later decreased systematically. However, this is not to say that the movement disappeared. The organizations included in the governing coalition adopted different strategies from those chosen by the organizations that refused to participate in government (Pereyra et al. 2008). By 2008, the process of reincorporation had begun to stagnate, most probably foreshadowing the end of this historical period in 2009.

The period of reincorporation started during Duhalde's (PJ) presidency (20023) through the government's attempt at state territorial reincorporation, so as to enable demobilization during a very contentious period initiated by the collapse of De la Rúa's and then Rodríguez Saás governments. Duhalde's administration publicly promised to expand subsidies to a total of two million beneficiaries, but under a new system. This decision implied the expansion of the restricted piquetero policy domain to a general policy constituency. The new subsidy system was called Programa Jefes y Jefas de Hogar Desocupados (PJJHD), and became part of a redefinition of the state's approach to the legitimated piquetero movement and its claim for reincorporation. From then on, this relationship would evolve into an agreement for the sustainability of governability between the FTV, CCC, and Duhalde (Rossi forthcoming). The government also called for a Social-Christian approach to the resolution of social conflicts through the constitution of a space for negotiation and articulation inspired by the Moncloa Pact. This space, called Mesa del Diálogo Argentino, would be the responsibility of the Catholic Church and the United Nations Development Program for Argentina. In addition to all parties and unions, the FTV, CCC, and MIJD went on to participate in it, while the rest of the movement refused to join it. At the same time, the rest of the movement, which opted not to support the government, adopted a confrontational strategy. This sector clash with the government led to the killing of two piqueteros during a picket on Pueyrredón Bridge in 2002, delegitimating the government and leading to the call for early presidential elections in 2003.

After the elections, a joint government agreement was established between Duhalde and the new president, Néstor Kirchner, between 2003 and 2005. When this agreement ended, the process expanded and consolidated, being redefined as a dynamic of party territorial reincorporation. In this period, the inclusion of piquetero organizations in the governing coalition was part of the PJ strategy to rebuild territorial support, along with the mobilization capacity that had been lost since the party was deunionized as a result of the PJ detachment from the CGT. The two main modes of reincorporation used initially by Duhalde's and later by Kirchner's government were the mobilization of the piqueteros for electoral purposes and the secondary inclusion of the movement in the piqueteros' policy domain. How- 
ever, these links between piquetero organizations, the party, and state institutions were set up individually through informal brokers (operadores); these arrangements led to agreements that had generally weak levels of transdistrict validity, due to the structure of the PJ and political territorialization, which increases the segmentation of political dynamics. Since 2003, the reincorporation process had been partly associated with attempts to create the national-populist party and movement Frente para la Victoria (FV). The FV included the PJ and other parties, as well as some piquetero organizations and state agents, until Néstor Kirchner opted to become PJ president in 2008.

During Néstor Kirchner's mandate, the piquetero movement began to be considered part of the territorial allied sector of the government. The first representatives of the piqueteros joined the executive and legislative branches in 2005 . Piqueteros took many, but secondary, roles in the Ministries of Social Development, Federal Planning, and even International Relations, but they could never occupy an agency in the trade union-controlled Ministry of Labor.

In 2007 the first piqueteros were elected national and provincial deputies. Some of the most relevant results for the piqueteros were in the provinces of Buenos Aires (FTV, Barrios de Pie, Movimiento "Evita"), and Salta (PO), and in the national parliament (MTD of La Juanita, Barrios de Pie, Movimiento "Evita"). These electoral outcomes were the result not of co-optation of the movement but of an expansion of the number of legitimate actors in the electoral arena. Piqueteros' access to legislative seats was not limited to the members of the coalition in government (FTV, Barrios de Pie, Movimiento "Evita"), as it was also achieved by piqueteros in the opposition (PO with the Partido Obrero, and the MTD of La Juanita with the Coalición Cívica). In subsequent elections, the number of piqueteros in parliament has increased.

The period of reincorporation can also be associated with an increasingly formal interaction between state institutions and movement organizations, thereby reducing the importance of informal state brokers. For the movement, the redefinition of this relationship meant the incorporation of the main leaders of the FTV, Barrios de Pie, and the Movimiento "Evita" into executive posts and the transformation of the role of the General Secretariat of the Presidency. After 2005, this government department became the main space for piquetero participation in the state apparatus. This office was occupied by some piqueteros in combination with PJ operadores, and its role was to mediate the piqueteros' relationship with executive departments.

This process was highly informal, and evolved over time, but always occurred without debating the elaboration of public policies. The actual purpose of the General Secretariat was to build a routinized relationship equivalent to the corporatist one, but for actors and conflicts of a territorial nature. From 2005 to 2007, the collegiate body of piqueteros in the General Secretariat was relatively stable: its members consisted of one from each allied piquetero organization and the CTA faction Frente Transversal Nacional y Popular. Their relationship was as coalition allies, and only the FTV would eventually suffer from the co-optation of its representative in 2005. In 2009 the activities of these piqueteros ended, due to marginal results and the increased space conferred on the PJ in the coalition, to the piqueteros' detriment. As 
part of a process of increased institutionalization, this informal space was replaced with the Sub-Secretariat of Relationships with Civil Society.

For the piqueteros who were working with the government, this process of incorporation demonstrated the limits of the process itself. The role given to the piqueteros and the impossibility of transcending the PJ structure of horizontally and vertically uncoordinated informal, individualized, and territorialized links meant that the piqueteros were secondary actors with a reduced capacity to influence the public policy process. For the piqueteros who were external to the government (mainly the CCC, PO, MIJD, MTD of La Juanita, and Frente Popular "Darío Santillán"), this process did not imply having other piqueteros as allies inside the government who could help in the provision of resources or for the coordination of political actions. Instead, it represented the increased competition for resources among the "insider" and "outsider" piqueteros, which reduced the opportunities for mobilization for those groups that had not joined the governing coalition.

In this period, the divisions between state levels were less significant, as the proKirchner PJ factions gradually began to control the national, provincial, and local levels of government, reducing the intensity of disputes among governors, mayors, and the president. Néstor Kirchner's government also ended the distribution of PJJHD and defined institutional tasks related to the "piquetero question." Even though the responsibility for all unemployment programs and subsidies always remained under the control of the Secretariat of Employment, following the sanctioning of Decree 1506 in 2004, an innovation in the piqueteros' policy domain was added. For the first time ever since the emergence of the "piquetero question," this decree established a clear distribution of roles for this policy domain between the Ministry of Labor and the Ministry of Social Development. Henceforth, the Ministry of Labor's responsibility over subsidies distribution would be confirmed as exclusive. In addition, the Ministry of Social Development gained responsibility for the rest of the social policies related to the piqueteros' policy domain (the territorial claims for access to water, health, etc.), except for the subsidies that helped unemployed people needing training to re-enter the labor market. Only a third ministry, the new, Keynesian-style Ministry of Federal Planning, would be directly involved in the piqueteros' policy domain, and this was mainly for home building and legalizing occupied land. In historical terms, the gradual institutionalization of the new "social question" that started during the recognition stage of this dispute on the responsibility of the piqueteros' policy domain was closed with the sanctioning of Decree 1506 , as a result of the formalization of unemployed workers' territorial reincorporation.

The second incorporation process implied the end of the hegemonic role of the PJ and CGT as interlocutors for the popular sectors' demands. First, the union system was liberalized, and as a result, the CGT lost the exclusive representation of incorporated workers when the CTA was founded. Second, the piqueteros emerged as the main actor to challenge the PJ's almost total hegemony in the territory. The effects of reincorporation for both the disincorporated and the incorporated workers were equally significant: for the incorporated workers, the union system became 
moderately pluralist and more autonomous from the PJ; for the reincorporated workers, a noncorporatist path materialized in the newly created institutions.

Since its origins, the piquetero movement has diversified. This has made it harder for the movement to promote long-lasting common strategies and has also led to widespread fragmentation, which has many causes. First, the left has a tendency to produce splits on the basis of ideologically dogmatic or personalized differences. Forming part of the leftist community, the movement was equally affected by this tendency. Second, interaction with the PJ—a party that is fragmented, territorially uncoordinated, and personalized-meant that the piqueteros tended to organize themselves along the same lines, tailoring links by district. Third, the multilevel routine and contentious disputes encouraged by the federal regime in Argentina favored the division of the piqueteros by district. ${ }^{21}$ In other words, divisions by province were added to the multiple PJ divisions.

To sum up, the 17 national piquetero organizations are the result of the multiplicity of PJ factions governing locally with different styles and links to the movement, which has reinforced the left's historical tendency to factionalize. However, the fragmentation of the movement does not mean that there has been more than one reincorporation process, but rather that the process of second incorporation has followed a fragmented, territorial logic, as distinct from the corporatist, centralized logic of first incorporation.

Several other changes occurred in Argentina resulting from the struggle for second incorporation. Heterodox economic policies that mixed neoclassical with statist principles in pragmatic and selective interventions in the market economy replaced the neoliberal approach that previously had dominated (Levitsky and Roberts 2011a, 21). Even though incorporation should not be equated with a necessary increase in welfare, in Argentina some socioeconomic figures improved during this second wave. Unemployment fell to 7.3 percent in 2010, and a considerable number of social policies were enacted, covering 1,990,735 unemployed persons in 2003. Since then, these policies have been considered one of the main causes of the sharp decrease in inequality (Lustig et al. 2012). The economy was partially reindustrialized (the value added by the manufacturing sectors represented 24.08 percent of the GDP in 2004) (INDEC 2010; Ministry of Labor 2003-10; Ministry of Social Development 2007-9; World Bank 2010).

New institutions, such as the Ministry of Social Development and the Ministry of Federal Planning, were created to make Keynesian-style policies more robust. In addition, in political terms, some piquetero organizations were incorporated into the governing coalition in 2002 (extended in 2005); others were elected to the national and some provincial parliaments in 2007; and several hundred piqueteros started to participate in municipal governments (as mayors, city councilors, and nonelected public officials), mainly in Buenos Aires, Córdoba, Santa Fe, Salta, and Tucumán. Alterations made to the Procedural Penal Code adapted the role of the security forces to bolster their capacity to handle the social unrest that emerged during the struggle for reincorporation. Furthermore, the territorialized logic of political disputes has emerged as a key component of Argentine politics. 
The territorial reincorporation of the popular sectors led to two main disputes. The first was for the hegemony of territorial mobilization. Once the piqueteros emerged as a legitimate national actor, they entered into conflict with the main PJ territorial source of mobilization, the mayors of GBA. The second dispute concerned the constituency of the popular sectors. The reincorporation process gave rise to a dispute between the organizations of those workers who had already been incorporated (unions) and those who had been disincorporated (piqueteros).

The second wave of incorporation of the popular sectors had some limits. Territorial reincorporation implied the first massive mobilization of the poor by nonPeronist political organizations since $1945 .{ }^{22}$ However, the divisions within the movement, together with the resilience of Peronist popular culture, prevented the piquetero movement from producing a change in the political culture among the popular sectors.

\section{Conclusions}

This article has argued that neoliberalism-at least in Argentina-has led to the emergence of a movement of disincorporated workers that has been struggling for the reincorporation of the popular sectors into the sociopolitical arena as part of the wage-earning society. While the first incorporation was a corporatist process with Peronist trade unions as the main contentious actors, the second was a territorialized process in which the non-Peronist piquetero movement was the primary actor. The second incorporation followed a multiscalar (local, provincial, national) series of territorially based interactions. Consequently, the second incorporation in Argentina can be defined as a type of party territorial incorporation because it was done with the goal of channeling the territorial mobilization inherited from the resistance to disincorporation in the electoral strategy of Kirchnerism.

This article has also identified the main actor of the second incorporation in Argentina, the piquetero movement. This movement represents a paradigmatic case of what I call reincorporation movements. This type of movement can be defined as one associated with the struggle for inclusion in the postneoliberal political arena. Reincorporation movements share many of the longstanding characteristics of the demands made by popular sector movements for social transformation through inclusion by way of revolution or reform. ${ }^{23}$ They also have specific attributes that define them as particular expressions of the historical process of struggle for incorporation that emerged due to neoliberal reforms.

However, this is not a story unique to Argentina. Latin America went through a cycle of continental mobilization against neoliberal disincorporation from the mid-1990s to the first decade of the 2000s (Schefner et al. 2006; Almeida 2007; Silva 2009). These mobilizations were not limited to resistance struggles, as the reshaped political arenas of several countries following the reincorporation of urban or rural popular sectors show. ${ }^{24}$ Although this article has focused on Argentina, arguments concerning the struggles for reincorporation are equally valid elsewhere. 
Therefore, this article poses a critical question for future comparative research: does the shift from corporatist to territorial incorporation appear in other Latin American countries that have experienced the same neoliberal reforms as Argentina? The conceptualization of reincorporation movements and struggles could just as easily be applied to other Latin American cases, such as the landless peasants' movement in Brazil, which struggles for urban and rural reincorporation. According to some authors, the main struggle of the landless peasants' movement has been for their "recognition as not only workers, but as persons with the right of being paid for their work. ... Peasants, thus, want social changes that lead to their recognition as members of society" (Martins 1994, 156, quoted in Fernandes 2000, 21). They have been struggling for the same goal as the piqueteros: their reincorporation as wage earners (members of the socioeconomic society) as well as citizens (members of the political society).

Fernandes $(1998,47-48)$ contends that the growth of rural unrest during the 1990 s was a result of the negative impact of neoliberalism in the urban and rural popular sectors, pursuing land occupation as an alternative quest for socioeconomic integration. Moreover, Pereira $(2003,49-50)$ quotes sources that say that in the 1990s, around 40 percent of the landless peasants mobilized for land reform were previously urban unemployed popular sectors. While in Argentina the resistance to neoliberalism and the quest for reincorporation was framed as an urban problem, in Brazil it was framed in rural terms because a legal framework inherited from the first incorporation (mainly, the Estatuto da Terra of 1964) was consolidated during democratization with Article 184 (about the social utility of land) in the 1988 Constitution. This built a tradition of institutions and actors that made this policy area more favorable for reincorporation struggles than the urban one. ${ }^{25}$

Equally significant has been the introduction of the "indigenous social question" by indigenous movements in Bolivia, Ecuador, Guatemala, and Mexico (Yashar 2005; Lucero 2008). Even though indigenous movements in Latin America achieved "first" incorporation during their struggles against neoliberal policies, in national terms and as part of the popular sectors (as broadly defined), indigenous peoples had already been incorporated as "peasants" during the ISI era. The emergence of a social question involving stronger ethnic and territorial identifications than those raised during the ISI era is a trend common to the second incorporation period. Since the 1990s, the struggles for recognition of indigenous peoples as part of the polity in the Andean region have evolved into reincorporation struggles (Van Cott 2005; Lucero 2008; Pearce 2011), and in some cases, organizations have even reached government office.

Although other countries are not analyzed here, arguments about the second wave of incorporation could also be applied to Bolivia, Brazil, Ecuador, and Venezuela (while necessarily bearing in mind each country's specificities). In those countries where reincorporation might have happened, we could expect considerable variation in the path and pace taken. Concerning the territorialization of second incorporation, the most important sources of variance seem to be four. First, the profundity of the reformulation of the locus of politics conducted by the last 
authoritarian military regime in each country, whereby democratization proceeded from the local to the national level. Second, the effect wrought by neoliberalism on the mainstream parties claiming to represent popular sectors. Third, the ways that the trade union system was modeled by the corporatist period and remodeled by neoliberalism. Fourth, how the first incorporation of the popular sectors (urban or rural) was produced and how its achievements have been eroded by the military regimes and neoliberalism.

Affecting all these cross-nationally is the timing of each particular process. Reincorporation may be a relatively quick process, as it was in urban Argentina after 2002; long processes brought on by several regime breakdowns, as in Bolivia and Ecuador; or even the result of gradual change over the course of a protracted struggle, as in Brazil. Moreover, reincorporation processes involve the remobilization of popular sectors in more than defensive struggles, but this does not necessarily imply the ideological transformation of the popular sectors' political culture. In Argentina, Peronism has continued to supply the main political ethos of the popular sectors, while Katarism has emerged as relevant for Bolivian coca growers' movements (Yashar 2005; Lucero 2008).

However, all these cases share some traits. The struggle against disincorporation was a contentious one, which included a reincorporation movement (e.g., indigenous and coca growers in Bolivia, indigenous in Ecuador, landless peasants in Brazil). Later on, reincorporation was conducted in territorial terms, with institutions such as the territórios da cidadania in Brazil (Delgado and Leite 2011), the misiones in Venezuela (Ellner 2008), and the partly formalized articulation of movement claims through the General Secretariat of the Presidency in Bolivia and Brazil. Also, new institutions, such as social councils, were created to deal with multiple noncorporatist claims in Brazil (Doctor 2007), and even constitutional reforms in Bolivia, Ecuador, and Venezuela were promoted to deal with the new "social question" (Lupien 2011).

Thus the theoretical and historical approach proposed here could be potentially useful for the purposes of defining the common characteristics of the struggles for reincorporation and the second wave of (territorial) incorporation in Latin America. However, it is only after the sedimentation of these transformations in the decades to come that we will be able to evaluate the long-term impact of this important shift from a corporatist to a territorial incorporation. Further single-case and comparative research has yet to be conducted on this agenda to answer this and other related questions.

\section{Notes}

I am very grateful to Leonardo Avritzer, Donatella della Porta, Jeff Goodwin, Nicky Owtram, Leigh Payne, Tim Peace, Kenneth Roberts, Philippe Schmitter, Sidney Tarrow, Marisa von Bülow, the editors of LAPS, and three anonymous reviewers for their helpful comments. I presented earlier versions of this article at the Conference "Latin America and the Caribbean: Beyond Neoliberalism?” (University of Groningen, November 18-19, 2010), the Sixth General Conference of the European Consortium for Political Research (University of Iceland, August 24-27, 2011), the Center for Latin American Studies, University of Pitts- 
burgh (November 8, 2012), and the Conference "Contentions Against Neoliberalism: Reconstituting the Social Fabric in the Developing World" (Department of International Development, University of Oxford, June 27-28, 2013). The ideas and concepts contained in this article were originally developed in my doctoral dissertation at the European University Institute (2011).

1. This article uses the terms popular sectors, workers, and urban-rural poor interchangeably to refer to the same socioeconomic segment of society, which in Spanish is commonly rendered as sectores populares.

2. When dealing with "(re)incorporation" as a concept, I am following Collier and Collier 1991, rather than social movement scholars' conceptualization of this term (Giugni 1998). This is because, rather than considering incorporation as an immediate outcome of social movement struggles, I understand it as a Latin American macrohistorical process.

3. The name piqueteros (picketers) derives from the type of protest for which the movement became widely known: the picketing or roadblocking of main national roads to call for jobs, unemployment subsidies, food, and so on.

4. The sources for this article are three fieldwork periods in Argentina between 2007 and 2009, which included 37 in-depth semistructured interviews with piquetero leaders, national ministries, national and provincial parliamentarians, mayors, union leaders, priests, informal party and state brokers, human rights activists, and journalists. In addition, I collected and systematized about 2,000 newspaper articles from all national newspapers of Argentina, covering the period 1994-2009. I also collected archival material elaborated by the main organizations of the piquetero movement and documents published by the main government departments dealing with the claims of this movement, such as the Ministry of Social Development.

5. I follow the definition of postneoliberalism of Grugel and Riggirozzi 2012, 3. Some studies of contentious politics during neoliberalism are Auyero 2003; Lucero 2008; Burdick et al. 2009; and Silva 2009.

6. Honneth $(1995,165)$ argues that "the models of conflict that start from collective feelings of having been unjustly treated are those that trace the emergence and the course of social struggles back to moral experiences of social groups who face having legal or social recognition withheld from them. In the first case, we are dealing with the analysis of competition for scarce goods, whereas in the second case, we are dealing with the analysis of a struggle over the intersubjective conditions for personal integrity." Hobson (2003), by contrast, contends that the materialistic struggle is neither detached from nor opposed to that for recognition. Moreover, "Recognition struggles often involve making claims for resources, goods, and services through state policies.... But claims in recognition struggles are also connected to membership and inclusion in the polity" (Hobson 2003, 3).

7. For this conceptual proposal, I have not followed Sartori's 1970 logic of concept formation, but rather the approach of Collier and Mahon (1993, 851, n. 8) for the formation of radial categories: "with radial categories it is possible that two members of the category will not share all of what may be seen as the defining attributes ... with radial categories the overall meaning of a category is anchored in a 'central subcategory,' which corresponds to the 'best' case, or prototype, of the category. In the process of cognition, the central subcategory functions as a gestalt, in that it is constituted by a bundle of traits that are learned together, understood together, and most quickly recognized when found together. 'Noncentral subcategories' are variants of the central one. They do not necessarily share defining attributes with each other but only with the central subcategory-hence the term radial, which refers to this internal structure" (Collier and Mahon 1993, 848). 
8. Manin (1992) defines the "crisis of party communities" as the metamorphosis of political representation. Representation changed from a form based on programmatic parties reflecting the concerns of social classes or communities to a more personality-based form of politics, in which a multidimensional society is represented through governing elites that attempt to interpret public opinion.

9. This means that reincorporation movements can follow multiple goals simultaneously, but incorporation must be the main medium-term focus. The use of "revolutionary" (or other) rhetoric by movements struggling for the second incorporation of the popular sectors does not mean that movement leaders are confused or uncertain about movement goals. Instead, it means that a movement can be defined as a "reincorporation movement" by its relation to a macrohistorical process of dis- or reincorporation, even though the main longterm goal for some organizations might be something else. Thus, following this definition, all movements that have struggled for the popular sectors' incorporation since neoliberal state reforms were applied can be defined as reincorporation movements, be this a short-, medium-, or long-term goal within "revolutionary," "reformist," or "conservative" rhetorical forms.

10. The details of the whole historical process of the first incorporation in Argentina have not been included, as this is not the aim of the article. The process has already been successfully analyzed by Collier and Collier (1991). This article focuses on the historical continuation of what these authors studied. However, the advances (1943-55), stalemates (196276), and setbacks (1976-96) that link the first and second incorporations should be taken into account as stages of the same historical process.

11. "Corporatism can be defined as a system of interest representation in which the constituent units are organized into a limited number of singular, compulsory, noncompetitive, hierarchically ordered and functionally differentiated categories, recognized or licensed (if not created) by the state and granted a deliberate representational monopoly within their respective categories in exchange for observing certain controls on their selection of leaders and articulation of demands and supports" (Schmitter 1974, 93-94).

12. For example, the social policies related to housing and habitat (Cravino 2013).

13. In some Latin American countries, the urban and rural poor were first incorporated into very unequal societies, as in Brazil under Getúlio Vargas; while in other countries, a more equal society and some welfare policies emerged as a result of incorporation, as in Argentina under Juan Domingo Perón.

14. Several wide-ranging reforms affected labor relations and corporatist mechanisms; for a description of these reforms, see Cook 2007.

15. In this sense, Roberts $(2002,19)$ argues, "neoliberal critical junctures produced sharp discontinuities in the labor-mobilizing systems. More than a simple epiphenomenon of economic crisis, this discontinuity reflects the collapse of a mode of political organization and representation that was deeply embedded in the previous development model and is increasingly out of sync with the socioeconomic landscape carved out by the process of free-market reforms. The stratified (or at least semistratified) cleavage structures and corporatist organizational practices of labor-mobilizing systems have been undermined by the individualizing logic of the neoliberal era, eroding class cleavages...."

16. McAdam et al. $(2008,325)$ define a siting decision as "the announcement by project and government officials of their intention to locate some substantial infrastructure project or facility in a given locale."

17. Policy domain here means "(1) the range of collective actors ... who have gained sufficient legitimacy to speak about or act on a particular issue; and (2) the cultural logics, 
frameworks, and ideologies those actors bring to bear in constructing and narrating the 'problem' and the appropriate policy responses" (Jenness et al. 2005, 300).

18. The Historical Rebuilding Fund for GBA was a regular provision of national resources, at the discretion of the administration of the province of Buenos Aires, of around US\$650 million annually, from 1992 to 2001 (Prévôt-Schapira 1996; Repetto 2000; La Nación 1998). This agreement was the most developed of a generic type of accord that Menem entered into with provincial governors in exchange for their support for his reform policies (Gibson and Calvo 2000).

19. I follow the definition of judicialization of Domingo (2004, 110).

20. Collier and Collier (1991, 162-68) define two types of incorporation based on (1) the goals of the elites, (2) whether the principal political agent is involved during the incorporation stage, (3) the mode, and (4) the scope of incorporation. While state incorporation is defined by the state's demobilization goals, promoted for the purpose of depoliticizing the labor movement, party incorporation is defined by mobilization goals for the electoral purposes of a movement or party — whether these are pre-existing or need to be created during the incorporation process.

21. The names of many piquetero organizations have been related to a neighborhood or district, showing their territorial sense of belonging (e.g., MTD of La Juanita, UTD of Mosconi). This association between organizations and territories existed since the origin of the movement but grew as the movement increased its level of diversification.

22. The piquetero movement includes Peronist groups. However, they are not the main ones; only 1 out of 17 organizations is related to the PJ, and no piquetero organizations are related to the CGT.

23. During the struggle for reincorporation, the piqueteros commonly made use of picketing and insurrectional direct actions for moderate claims, such as access to unemployment subsidies. In other words, the reincorporation movement, in its quest for bridging popular sectors with the state, recreated the balance that had already been used between the unions' radical methods of protest during the pre-incorporation period and their more formal negotiations with the government. (On the strategies in the struggle for first incorporation, see Collier and Collier 1991, 336-44).

24. I do not claim that each and every actor has been or is being reincorporated, but that the broader national process is one of reincorporation.

25. For a long-term historical perspective on the struggle for rural incorporation in Brazil, see Welch 2009.

\section{REFERENCES}

Almeida, Paul. 2007. Defensive Mobilization: Popular Movements Against Economic Adjustment Policies in Latin America. Latin American Perspectives 34, 3: 123-39.

Altimir, Oscar, and Luis Beccaria. 2001. El persistente deterioro de la distribución del ingreso en la Argentina. Desarrollo Económico 40, 160: 589-618.

Artese, Matías. 2009. Criminalización de la protesta en Argentina. Una construcción de lo delictivo más allá de la esfera jurídica. América Latina Hoy 52: 149-69.

Auyero, Javier. 2003. Contentious Lives: Two Argentine Women, Two Protests, and the Quest for Recognition. Durham: Duke University Press.

Becker, Mark. 2011. Pachakutik: Indigenous Movements and Electoral Politics in Ecuador. Lanham: Rowman \& Littlefield.

Burdick, John, Philip Oxhorn, and Kenneth Roberts, eds. 2009. Beyond Neoliberalism in Latin America? Societies and Politics at the Crossroads. New York: Palgrave Macmillan. 
Cameron, Maxwell A., and Eric Hershberg, eds. 2010. Latin America's Left Turns: Politics, Policies, and Trajectories of Change. Boulder: Lynne Rienner.

Cavarozzi, Marcelo, and Manuel Garretón. 1989. Muerte y resurrección: los partidos politicos en el autoritarismo y las transiciones en el Cono Sur. Santiago: FLACSO.

Cerrutti, Marcela, and Alejandro Grimson. 2004. Buenos Aires, neoliberalismo y después. Cambios socioeconómicos y respuestas populares. Working Paper \#04-04d. Center for Migration and Development, Princeton University.

Clarin (Buenos Aires). 1998. Jugada clave: palito ya tiene lugar en el gobierno. April 9.

Collier, David, and James Mahon. 1993. Conceptual "Stretching" Revisited: Adapting Categories in Comparative Analysis. American Political Science Review 87, 4: 845-55.

Collier, Ruth Berins, and David Collier. 1991. Shaping the Political Arena: Critical Junctures, the Labor Movement, and Regime Dynamics in Latin America. Princeton: Princeton University Press.

Collier, Ruth Berins, and Samuel Handlin, eds. 2009a. Reorganizing Popular Politics: Participation and the New Interest Regime in Latin America. University Park: Pennsylvania State University Press.

2009b. Situating the Analysis: Analytic Approach, Cases, and Historical Context. In Collier and Handlin 2009a. 32-60.

Cook, María Lorena. 2007. The Politics of Labor Reform in Latin America: Between Flexibility and Rights. University Park: Pennsylvania State University Press.

Cravino, María Cristina, ed. 2013. Construyendo barrios. Transformaciones socioterritoriales a partir de los Programas Federales de Vivienda en el Area Metropolitana de Buenos Aires (2004-2009). Buenos Aires: UNGS-Ciccus.

Delamata, Gabriela. 2002. De los “estallidos” provinciales a la generalización de la protesta en Argentina. Perspectiva y contexto en la significación de las nuevas protestas. Nueva Sociedad 182: 121-37.

Delgado, Nelson, and Sergio Leite. 2011. Políticas de desenvolvimento territorial no meio rural brasileiro: novas institucionalidades e protagonismo dos atores. Dados 54, 2: 43173.

Doctor, Mahrukh. 2007. Lula's Development Council: Neo-Corporatism and Policy Reform in Brazil. Latin American Perspectives 34, 6: 131-48.

Domingo, Pilar. 2004. Judicialization of Politics or Politicization of the Judiciary? Recent Trends in Latin America. Democratization 11, 1: 104-26.

Ellner, Steve. 2008. Rethinking Venezuelan Politics: Class, Conflict, and the Chávez Phenomenon. Boulder: Lynne Rienner.

Epstein, Edward. 1987. Inflation and Public Policy in Argentina. Boletín de Estudios Latinoamericanos y del Caribe 51: 81-97.

Etchemendy, Sebastián, and Ruth Berins Collier. 2007. Down But Not Out: Union Resurgence and Segmented Neocorporatism in Argentina (2003-2007). Politics \& Society 35, 3: 363-401.

Farinetti, Marina. 1999. ¿Qué queda del movimiento obrero? Las formas del reclamo laboral en la nueva democracia argentina. Trabajo y Sociedad 1, 1: 1-34.

Fernandes, Bernardo. 2000. A formação do MST no Brasil. Petrópolis: Vozes.

Flores-Macías, Gustavo. 2012. After Neoliberalism? The Left and Economic Reforms in Latin America. New York: Oxford University Press.

Gaudio, Ricardo, and Jorge Pilone. 1983. El desarrollo de la negociación colectiva durante la etapa de modernización industrial en la Argentina, 1935-1943. Desarrollo Económico 23, 90: 255-86. 
1984. Estado y relaciones laborales en el período previo al surgimiento del peronismo, 1935-1943. Desarrollo Económico 24, 235-73.

Gibson, Edward, and Ernesto Calvo. 2000. Federalism and Low-Maintenance Constituencies: Territorial Dimensions of Economic Reform in Argentina. Studies in Comparative International Development 35, 3: 32-55.

Gibson, Edward, and Tulia Falleti. 2004. Unity by the Stick: Regional Conflict and the Origins of Argentine Federalism. In Federalism and Democracy in Latin America, ed. Gibson. Baltimore: Johns Hopkins University Press. 226-54.

Giraudy, Agustina. 2007. The Distributive Politics of Emergency Employment Programs in Argentina, 1993-2002. Latin American Research Review 42, 2: 33-55.

Giugni, Marco. 1998. Social Movements and Change: Incorporation, Transformation, and Democratization. In From Contention to Democracy, ed. Giugni, Doug McAdam, and Charles Tilly. Lanham: Rowman \& Littlefield. xi-xxiii.

Grugel, Jean, and Pía Riggirozzi, eds. 2009. Governance After Neoliberalism in Latin America. New York: Palgrave Macmillan.

- 2012. Post-Neoliberalism in Latin America: Rebuilding and Reclaiming the State After Crisis. Development \& Change 43, 1: 1-21.

Haggard, Stephan, and Robert Kaufman. 1995. The Political Economy of Democratic Transitions. Princeton: Princeton University Press.

Herrera, María Rosa. 2008. La contienda política en Argentina, 1997-2002: un ciclo de protesta. América Latina Hoy 48: 165-89.

Hobson, Barbara. 2003. Introduction. In Recognition Struggles and Social Movements: Contested Identities, Agency and Power, ed. Hobson. Cambridge: Cambridge University Press. 1-17.

Honneth, Axel. 1995. The Struggle for Recognition: The Moral Grammar of Social Conflicts. Cambridge: Polity Press.

Huber, Evelyne, and John Stephens. 2012. Democracy and the Left: Social Policy and Inequality in Latin America. Chicago: University of Chicago Press.

Instituto Nacional de Estadísticas y Censos (INDEC). 1974-2003. Datos de evolución de las tasas de actividad, empleo, desocupación y subocupación. www.indec.gob.ar/nuevaweb/ cuadros/4/shempleo1.xls

- 2010. Census 2010. www.indec.mecon.gob.ar

Isuani, Ernesto. 1985. Los origenes conflictivos de la seguridad social argentina. Buenos Aires: Centro Editor de América Latina.

Jenness, Valerie, David S. Meyer, and Helen Ingram. 2005. Conclusion: Social Movements, Public Policy, and Democracy: Rethinking the Nexus. In Routing the Opposition: Social Movements, Public Policy, and Democracy, ed. Meyer, Jenness, and Ingram. Minneapolis: University of Minnesota Press. 288-306.

Levitsky, Steven. 2003. Transforming Labor-Based Parties in Latin America: Argentine Peronism in Comparative Perspective. Cambridge: Cambridge University Press.

Levitsky, Steven, and Kenneth M. Roberts. 2011a. Latin America's "Left Turn": A Framework for Analysis. In Levitsky and Roberts 2011b. 1-28.

Levitsky, Steven, and Kenneth M. Roberts, eds. 2011b. The Resurgence of the Latin American Left. Baltimore: Johns Hopkins University Press.

Lodola, Germán. 2005. Protesta popular y redes clientelares en la Argentina: el reparto federal del Plan Trabajar (1996-2001). Desarrollo Económico 44, 176: 515-16.

Lucero, José Antonio. 2008. Struggles of Voice: The Politics of Indigenous Representation in the Andes. Pittsburgh: University of Pittsburgh Press. 
Lupien, Pascal. 2011. The Incorporation of Indigenous Concepts of Plurinationality into the New Constitutions of Ecuador and Bolivia. Democratization 18, 3: 774-96.

Lustig, Nora, et al. 2012. The Impact of Taxes and Social Spending on Inequality and Poverty in Argentina, Bolivia, Brazil, Mexico, and Peru: A Synthesis of Results. Commitment to Equity (CEQ) Working Paper 311. New Orleans: Tulane University.

Manin, Bernard. 1992. Metamorfosis de la representación. In ¿Qué queda de la representación política? ed. Mario Dos Santos. Caracas: CLACSO/Nueva Sociedad. 9-40.

Martins, Jose de Souza. 1994. O poder do atraso: ensaios de sociologia da história lenta. São Paulo: Hucitec.

McAdam, Doug, Sidney Tarrow, and Charles Tilly. 2008. Methods for Measuring Mechanisms of Contention. Qualitative Sociology 31, 4: 307-31.

McGuire, James. 1997. Peronism Without Perón: Unions, Parties, and Democracy in Argentina. Stanford: Stanford University Press.

Merklen, Denis. 2005. Pobres ciudadanos. Las clases populares en la era democrática (Argentina, 1983-2003). Buenos Aires: Gorla.

Ministry of Labor. 2003-10. Informes y estadísticas 2003-2010 de la Unidad de Monitoreo del Programa Jefes y Jefas de Hogar Desocupados. www.trabajo.gov.ar/jefes/infostats/ index.asp

Ministry of Social Development. 2009. Rendimos cuentas: diciembre 2007-mayo 2009. Buenos Aires: Ministerio de Desarrollo Social de la Nación. www.desarrollosocial.gob. ar/Uploads/i1/1.\%20Rendimos\%20Cuentas.pdf

La Nación (Buenos Aires). 1998. Menem pediría que se elimine el Fondo del Conurbano Bonaerense. January 29.

- 2004. Pitrola: el mero asistencialismo está en decadencia. April 6.

Novaro, Marcos, and Vicente Palermo. 2003. La dictadura militar, 1976-1983: del golpe de estado a la restauración democrática. Buenos Aires: Paidós.

O'Donnell, Guillermo. 1973. Modernization and Bureaucratic-Authoritarianism: Studies in South American Politics. Berkeley: University of California Press.

1998. Bureaucratic Authoritarianism: Argentina, 1966-1973, in Comparative Perspective. Berkeley: University of California Press.

Ondetti, Gabriel. 2008. Land, Protest, and Politics: The Landless Movement and the Struggle for Agrarian Reform in Brazil. University Park: Pennsylvania State University Press.

Orlansky, Dora. 1998. Las políticas de descentralización. Desarrollo Económico 38, 151: 827-44.

Oszlak, Oscar. 2003. El mito del estado mínimo: una década de reforma estatal en la Argentina. Desarrollo Económico 42, 168: 519-43.

Oxhorn, Philip. 1998. Is the Century of Corporatism Over? Neoliberalism and the Rise of Neopluralism. In What Kind of Democracy? What Kind of Market? Latin America in the Age of Neoliberalism, ed. Oxhorn and Graciela Ducatenzeiler. University Park: Pennsylvania State University Press. 195-217.

Página/12 (Buenos Aires). 1998. Empezó la pelea por los fondos, Erman no le cede nada a Ortega. April 15.

- 2001. En Salta estrenaron las reformas penales. June 21.

Palermo, Vicente, and Marcos Novaro, eds. 1996. Politica y poder en el gobierno de Menem. Buenos Aires: Norma.

Panizza, Francisco. 2009. Contemporary Latin America: Development and Democracy Beyond the Washington Consensus. London: Zed Books.

Pearce, Adrian. 2011. Evo Morales and the Movimiento al Socialismo in Bolivia: The First Term in Context, 2006-2010. London: Institute for the Study of the Americas. 
Pereira, Anthony. 2003. Brazil's Agrarian Reform: Democratic Innovation or Oligarchic Exclusion Redux? Latin American Politics and Society 45, 2 (Summer): 41-65.

Pereyra, Sebastián, Germán Pérez, and Federico Schuster, eds. 2008. La huella piquetera. Avatares de las organizaciones de desocupados después de 2001. La Plata: Al Margen.

Pérez, Germán, and Ana Natalucci. 2012. "Vamos las bandas": organizaciones y militancia kirchnerista. Buenos Aires: Nueva Trilce.

Portes, Alejandro, and Kelly Hoffmann. 2003. Latin American Class Structures: Their Composition and Change During the Neoliberal Era. Latin American Research Review 38, 1: 41-82.

Prévôt-Schapira, Marie-France. 1996. Las políticas de lucha contra la pobreza en la periferia de Buenos Aires, 1984-1994. Revista Mexicana de Sociología 58, 2: 73-94.

Repetto, Fabián. 2000. Gestión pública, actores e institucionalidad: las políticas frente a la pobreza en los '90. Desarrollo Económico 39, 156: 597-618.

Roberts, Kenneth M. 2002. Social Inequalities Without Class Cleavages in Latin America's Neoliberal Era. Studies in Comparative International Development 36, 4: 3-33.

- 2008. The Mobilization of Opposition to Economic Liberalization. Annual Review of Political Science 11, 1: 327-49.

Rossi, Federico M. 2013. Piqueteros (Workers/Unemployment Movement in Argentina). In The Wiley-Blackwell Encyclopedia of Social and Political Movements, ed. David Snow, Donatella della Porta, Bert Klandermans, and Doug McAdam. Oxford: Wiley-Blackwell. 929-32.

- Forthcoming. Beyond Clientelism: The Piquetero Movement and the State in Argentina. In Handbook of Social Movements Across Latin America, ed. Paul Almeida and Allen Cordero. New York: Springer.

Saad-Filho, Alfredo, Francesca Iannini, and Elizabeth Jean Molinari 2007. Neoliberalism, Democracy and Economic Policy in Latin America. In Political Economy of Latin America: Recent Economic Performance, ed. Philip Arestis and Malcolm Sawyer. New York: Palgrave Macmillan. 1-35.

Sánchez, Pilar. 1997. El Cutralcazo: la pueblada de Cutral Co y Plaza Huincul. Buenos Aires: Agora.

Sartori, Giovanni. 1970. Concept Misformation in Comparative Politics. American Political Science Review 64, 4: 1033-53.

Schefner, Jon, George Pasdirtz, and Cory Blad. 2006. Austerity Protests and Immiserating Growth in Mexico and Argentina. In Latin American Social Movements: Globalization, Democratization and Transnational Networks, ed. Hank Johnston and Paul Almeida. Lanham: Rowman \& Littlefield. 19-41.

Schmitter, Philippe C. 1974. Still the Century of Corporatism? Review of Politics 36, 1: 85131.

Schuster, Federico et al. 2006. Transformaciones en la protesta social en Argentina, 19892003. Documentos de trabajo 48. Buenos Aires: Instituto de Investigaciones "Gino Germani," Universidad de Buenos Aires.

Schvarzer, Jorge. 1998. Economic Reform in Argentina: Which Social Forces for What Aims? In What Kind of Democracy? What Kind of Market? Latin America in the Age of Neoliberalism, ed. Philip Oxhorn and Graciela Ducatenzeiler. University Park: Pennsylvania State University Press. 61-88.

Silva, Eduardo. 2009. Challenging Neoliberalism in Latin America. New York: Cambridge University Press. 
Smith, William C., Carlos H. Acuña, and Eduardo A. Gamarra, eds. 1994. Latin American Political Economy in the Age of Neoliberal Reform: Theoretical and Comparative Perspectives for the 1990s. Coral Gables: North-South Center, University of Miami.

Suriano, Juan. 1988. Trabajadores, anarquismo y estado represor: de la Ley de Residencia a la Ley de Defensa Social (1902-1910). Buenos Aires: Centro Editor de América Latina. 2000. La cuestión social en Argentina, 1870-1943. Buenos Aires: La Colmena.

Svampa, Maristella, and Sebastián Pereyra. 2004. Entre la ruta y el barrio: la experiencia de las organizaciones piqueteras. 2nd ed. Buenos Aires: Biblos.

Tokman, Víctor, and Guillermo O'Donnell, eds. 1998. Poverty and Inequality in Latin America: Issues and New Challenges. Notre Dame: University of Notre Dame Press.

Van Cott, Donna. 2005. From Movements to Parties in Latin America: The Evolution of Ethnic Politics. New York: Cambridge University Press.

Weitz-Shapiro, Rebecca. 2006. Partisanship and Protest: The Politics of Workfare Distribution in Argentina. Latin American Research Review 41, 3: 122-47.

Welch, Cliff. 2009. Camponeses: Brazil's Peasant Movement in Historical Perspective (19462004). Latin American Perspectives 36, 4: 126-55.

Weyland, Kurt, Raul L. Madrid, and Wendy Hunter, eds. 2010. Leftist Governments in Latin America: Successes and Shortcomings. New York: Cambridge University Press.

World Bank. 2000. Implementation Report 41950-AR. Washington, DC: World Bank. 2010. Industry, Value Added (\% of GDP), Argentina. www.data.worldbank.org/ indicator/NV.IND.TOTL.ZS/countries/1W-AR-ZJ?display=graph

Yashar, Deborah J. 2005. Contesting Citizenship in Latin America: The Rise of Indigenous Movements and the Postliberal Challenge. New York: Cambridge University Press. 